\title{
Corporate Governance Quality, Stakeholders' Pressure, and Sustainable Development: An Integrated Approach
}

\author{
Akeel Almagtome \\ Faculty of Administration and Economics, \\ University of Kufa, Najaf, Iraq. \\ Corresponding author: akeelh.alhasnawi@uokufa.edu.iq \\ Maithm Khaghaany \\ Faculty of Administration and Economics, \\ University of Kufa, Najaf, Iraq. \\ E-mail: maithmm.khaghaany@uokufa.edu.iq \\ Saime Önce \\ Department of Business Administration, \\ Anadolu University, Eskişehir, Turkey. \\ E-mail: sonce@anadolu.edu.tr
}

(Received August 15, 2019; Accepted June 12, 2020)

\begin{abstract}
The goal of this paper is to explore the interrelated relationships between the quality of corporate governance, Stakeholder's pressure, and Sustainability Reporting. We claim that sustainable development strategies are the result of the interaction of two variables: the standard of corporate governance and the pressure of stakeholders rather than the outcome of a single variable. The results indicate that the company size and corporate governance rating are positively correlated with sustainability reporting Scores disclosed by the Turkish companies. The analysis of 125 firm-year data suggest that the company provides more SRS if it has a better corporate governance rating; or larger total assets. The paper also reveals that social, environmental and economic indicators, as pillars of sustainable development, are not the result of corporate governance practices or of stakeholder pressure alone, but represent a holistic reflection of the accumulated effects of various factors related to both corporate governance practices and stakeholder theory. This paper extends the work of Taşkirmaz, and Gamze (2017) which examined the relationship between corporate governance and corporate social responsibility. Our results increase understanding of sustainable practices of the circular economy in Turkish industrial companies and indicate future trends for these applications. This research will help managers of manufacturing companies in formulating their plans to maximize the use of available resources and improve efficiency in the context of the circular economy.
\end{abstract}

Keywords- Circular economy, Corporate governance, stakeholder theory, Accounting system, Sustainability reporting.

\section{Introduction}

The words "circular economy" and "sustainability" are widely appealing to academia, business and policy makers, but the similarities and distinctions between the two definitions remain ambiguous (Geissdoerfer et al., 2017). Sustainability seeks to tackle ecological and cultural and social-economic issues throughout the long-term. Generally, sustainability literature focusses primarily on environmental issues, while more specifically, the Circular Economy was presented as one of the most recent proposals for solving both environmental and economic problems. The goal of the Circular Economy is to turn waste into capital and to bridge production and consumption activities; however, there is still limited research focusing on these aspects (Witjes and Lozano, 2016). Recently, the sustainable practices of circular economy have dominated everywhere in the world, it 
emerged as success element, both at the firm level and at the society as a whole. Gradually, the sustainability issues start to get a special attention by a firm's management and board of directors to draw the firm's plans and strategies. In this regard, the implementation of a sustainable development approach requires the adoption of an appropriate corporate governance system in line with the spreading of corporate governance values and principles.

In this context, Salvioni and Astori (2013) argue that legal and regulatory practices and social responsibility are seen as prerequisites for sustainable development policy. At the same time, global capital markets usually require firms in emerging countries to adopt a complex corporate governance system that mimics leading practices in developed countries. Effective corporate governance leads to the security of shareholders' interests and, as a result, encourages the recruitment of new investors and reduces the cost of capital. Therefore, the quality of corporate governance procedures is a crucial tool to convince the international investors and to decrease the cost of capital concurrently. Moreover, the globalism in the context of capital markets enables the Turkish companies to attract a large pool of foreign investors as well as gaining the trust of international financial institutions, both in terms of financing and investment. Many multinational companies around the world have begun to pursue sustainable production methods and ecological system in managing their activities to address the ecological issues. Sustainable production polices and the ecological systems minimize waste generation and use of energy and materials (Moktadir et al., 2018). On the other hand, most successful companies throughout the world are currently adopting different versions of corporate governance practices. Such companies are continually working to improve and sustain their organizational systems in order to have a cohesive governance system capable of responding to the needs of stakeholders. In addition, companies are looking for a typical system that promotes their ability to deal with a complex business market and ensures a relevant environment for sustainable development. Generally, the policies adopted that concentrate on the values of social responsibility, equity and constructive relations between the organization and its shareholders influence the efficacy of corporate governance practices (Salvioni and Astori, 2013). Corporate governance in firms has generally been built on the principles of sustainability, which involve dissemination of information on social responsibility and stakeholder interests in firm activities. This change in the structure of corporate governance leads to significant improvements in the nature of decision-making and control functions. Due to the change in the information needs of decision making, the accountants need to respond to this change by extending the range of information disclosures to include providing useful sustainability information to stakeholders. Although Sustainable development is not a new concept, it has become popular over recent years. It is known as a development that protects the well-being of the current generation of human beings without harming the survival and living of future generations (Almagtome et al., 2019). The sustainable development is a triple concept that stands on the most essential pillars for society life, which include economic advancement, social equity, and environmental protection. In this context, Boeva et al. (2017) investigate the effect of sustainable development issues on the global supply chain by reviewing publicly available information on the social responsibility and sustainable development concerns of major international organizations. They indicate that under scarcity of economic resources the firms compete on a global economic level to achieve sustainability in all aspects related to social, environmental, and economic issues. In recent years, accounting literature has witnessed a shift towards activating the role of accounting information in enhancing the corporate sustainability through taking a step forward to produce information suitable to sustainability reporting practices. Although corporate governance practices have received high attention in the last three decades, the variations in firm-level corporate governance remain in the sustainability practices within the same country. Even though the development of sustainable business models, strategic planning and the extension of corporate 
International Journal of Mathematical, Engineering and Management Sciences

Vol. 5, No. 6, 1077-1090, 2020

https://doi.org/10.33889/IJMEMS.2020.5.6.082

reporting to include non-financial information show clear progress, a strong commitment to sustainability remains dubious in the long term.

This paper aims to explore the determinants of sustainability applications in the circular economy by employing both corporate governance and stakeholder theory in explaining management behavior. The study focuses on Turkey, a country with an emerging capital market that seeks to attract foreign investors by adopting a clear strategy to sustainable development, corporate governance, and transparency. Turkish companies are therefore increasingly moved to apply corporate governance principles, sustainability reporting guidelines and other forms of disclosure. Stakeholder Theory presents a framework to describe the role of the stakeholder in drawing up the firm's reporting strategy and, as a result, the firm's disclosure strategy can be interpreted as a response to pressure from external stakeholders (Almagtome, 2015). Thus, this paper examines the joint effect of the quality of corporate governance and stakeholders' pressure on sustainable development practices in Turkish companies.

\section{Literature Review}

\subsection{Quality of Corporate Governance and Sustainable}

Corporate governance is designed to foster the investment environment and create a stable financial state in capital markets through enhancing reliability, transparency, and accountability at the firmlevel. The corporate governance approach sets out the relationship between the various parties involved and the company, including the management of the business, the shareholders and other stakeholders. In order to maximize the stakeholder value, the board of directors should understand the nature of social and environmental consequences emanated from firm's operations. Further, the firms could be considered as operating in society under a contract whereby they are allowed to utilize society resources in their operations to produce products and services, without having an inherent right to these resources (Siva et al., 2016). Following the numerous scandals of fraudulent activities in financial reporting, corporate governance has become an international trend for many studies and has gained growing attention in financial and accounting literature to improve transparency and disclosure. In this context, Esty and Winston (2008) indicate that corporate governance seeks to increase the capability of stakeholders to create value by utilization of opportunities and management of risks related to environmental and social activities. In addition, the sustainability performance also has a positive association with the quality of corporate governance. In addition, De Villiers et al. (2011) states that there is a positive association between good environmental reporting and shareholder wealth, and the important objective of corporate boards to adhere to good environmental practices.

Regarding the sustainable practices of the circular economy, several studies have examined different aspects of sustainable practices and its reflections on the operations management such as (Al-Wattar et al., 2019; Ali et al., 2019; Kazimieras Zavadskas et al., 2019; Khaghaany et al., 2019; Kumar et al., 2020a; Kumar et al., 2020b; Luthra et al., 2020; Mangla et al., 2020; Panda et al., 2020) contrasts the efficiency of conventional and circular production processes across a number of measures. These studies indicate that the incorporation of circular economy concepts into environmental management could provide clear advantages from a sustainability point of view. In the same context, Sehnem et al. (2019) demonstrate that there is a correlation between sustainable activities and the assumptions of the circular economy. Schroeder et al. (2019) indicate that there is a strong relationship between the practices of circular economy and goals of sustainable development, In particular, the goals of (Safe drinking water), (Accessible and Clean Energy), (Respectable Employment and Job creation), (Liable Use and Manufacturing) and (Childhood on Territory). Mangla et al. (2019) indicate that 
industrial organizations will work on the supply chain to handle the logistics and distribution problems in order to reduce waste and mitigate financial losses and to take account of environmental issues. Khan et al. (2020) have shown that using renewable energy in logistics not only increases environmental sustainability but also create a better national image and offers better export prospects in environmentally responsible countries to support a sustainable growth economy. Besides, some researchers emphasize the quality of corporate governance and sustainability reporting. JamesOverheu and Cotter (2009) developed an index to measure the corporate governance derived from governance indicators that rely on governance principles of the Australian Stock Exchange. They indicate that both the quality of corporate governance and the disclosure of Sustainability are not significantly correlated to the company's default risk assessed by lenders. In addition, Pinkse and Kolk (2010) argue that firms require not only to be competitive, but also ethical, and that the ethical aspects reflect the company's authorization to operate. This means that there is an increasing divergence between the quality of corporate governance and the level of sustainability reporting. In this sense, the Board of Directors aims to ensure that the company is able to draw on community resources in its business operations by setting an organizational goal, plans and strategies that are consistent with societal needs. The good quality of corporate governance will therefore make the firm more socially and environmentally responsible and, in turn, more acceptable to stakeholders compared to those with poor quality governance. Michelon and Parbonetti (2012) demonstrate that understanding the impact of the composition of the board on sustainability reporting involves resolving the conventional distinction between independent and internal directors. Moreover, Chan et al. (2014) state that the firms that disclose more information on CSR have higher ratings of corporate governance, large size, belong to sensitive industry, and have a high leverage percentage. This result is consistent with prior research that suggests a positive association between quality of corporate governance and CSR disclosures. The characteristics of corporate governance are therefore a determinant of the level of sustainability reporting and reflect the firm's tendency to support a sustainable development strategy.

Boeva et al. (2017) indicate that there is a worldwide trend to make changes in corporate governance practices and the way by which the board of directors is managed due to the firm policy of sustainable development. This implies that the development of corporate governance is seen as a measure of the extent to which any company can support the national sustainable development strategy. Turkey is one of the few countries that have adopted a measure for corporate governance in a similar way to the regulations of corporate governance of other OECD countries. In 2005, the Turkish Capital market board (CMB) issued principles of corporate governance to be a guideline for Turkish companies. At the same time, the Istanbul Stock Exchange set up the Corporate Governance Index (CGI). Although the adoption of CGI is still optional and 48 Turkish companies listed on the Istanbul Stock Exchange are listed on that index in 2017, it is expected that the economic climate will lead the rest of the companies to be included in the CGI. In Turkey, all listed companies will declare and disclose whether or not they implement CGI and should document any new implementation of the principles of corporate governance. The principles of Turkish corporate governance are prepared in accordance with OECD principles (Esen et al., 2015). This includes four main sections;

(i) Shareholders, represents $25 \%$ of BIST score.

(ii) Disclosure and Transparency, represents $25 \%$ of CGI score.

(iii) Stakeholders, represents $15 \%$ of CGI score.

(iv) Board of directors, represents $35 \%$ of CGI score. 
International Journal of Mathematical, Engineering and Management Sciences

Vol. 5, No. 6, 1077-1090, 2020

https://doi.org/10.33889/IJMEMS.2020.5.6.082

The rating of corporate governance for each company is determined annually in accordance based on the principles of corporate governance indicated above. The rating process is responsibility of licensed rating agency, in Turkey SAHA is an official rating agency licensed by Turkish Markets Board (CMB).

\subsection{Stakeholders Pressure and Sustainability Reporting}

Sustainable behavioral factors and change management systems receive worldwide attention to the implementation of sustainable policies for the circular economic activities (Ahuja et al., 2019). The companies in most countries of the world seek to disclose their activities and sustainable practices through annual reports or sustainability reports and in a manner that reflects the eruption of various factors in management behavior. In this context, stakeholder theory is seen as an effective theoretical framework that explain the current and future trends in voluntary disclosure in accounting. It posits that effective management of the firm's relationship with its stakeholders is a crucial factor in the firm's success. It also offers a necessary structure to explain the relationship between stakeholder perceptions and the firm's reporting strategy, and the reporting strategy of the firm can be seen as being affected by stakeholder pressures under this theory (Almagtome, 2015). On the other hand, Stakeholder theory is seen as one of the essential topics in the field of social and environmental accounting. Most literature that deals with this theory concentrates on a proposition that links success of the firms with the effective management of firm-stakeholder relationships. Freeman (2010) disseminated the idea of stakeholders to apply to the interrelationships between companies and different groups of knowledge consumers, such as clients, shareholders, suppliers, society and the community. The firm must manage its relations with these groups in a manner that serves the interests of the firm and conveys a good image of its business activities in order to obtain the necessary credibility to function within the organization.

Stakeholder theory suggests that there are various stakeholders have various needs and anticipations, and accordingly the firms have several social contracts with different stakeholder groups. Internationally, stakeholder theory has become an important research method in social and environmental literature and is used as a way to determine and clarify why a business has implemented such social and environmental reporting practices. It is also used as a framework to identify the incentives and determinants of voluntary disclosure in both developing and developed countries (Almagtome et al., 2017). In this context, Snider et al. (2003) indicate that stakeholder theory is an appropriate framework to assess the corporate social responsibility of the companies. Aras and Crowther (2008) indicate that sustainability policy and corporate governance are core elements in the continuing operation of any firm, and that the firms pay an increasing attention to implement the procedures related to corporate governance. Kocmanová et al. (2011) focus on the integration of sustainability and corporate governance. They suggest that an efficient corporate governance structure in the business and in the economy as a whole will help to increase the trust and confidence needed to support the sustainability of the capital market. In the context of integration, the incorporating of environmental, social, and economic aspects of the firm into the corporate governance system constitutes a core element in drawing corporate strategy, and firm long-term goals. Schaltegger et al. (2012) state that there are two reasons to link the stakeholder interests with sustainability activities of the firm. The first is that the substantial feature of business activities is the sustainability which is reflected by creating economic value by voluntary social, and environmental activities. The second is that the value of creating sustainability activities for stakeholder groups will lead to the creation of economic value through support for sustainable development efforts. The common example about the correlation between value creation and stakeholder theory is that value creation for stakeholders can be made through high quality products, creating new jobs, pay taxes, or 
in the form of benefits for financial institutions. In the sense of sustainability, this definition often refers to the development of environmentally friendly goods that could allow employees to feel proud of themselves within the business. By reducing the amounts of pollution, the firm can get qualified and motivated workers and supportive local community.

Hörisch et al. (2014) identify three challenges of stakeholder relationship management under stakeholder theory, these challenges are;

- $\quad$ Supporting the certain sustainability interests of stakeholders.

- Creating mutual sustainability interests above certain interests, and

- Supporting stakeholders to be intermediaries for environment and sustainable development.

In order to overcome these challenges, they suggest that three interrelated elements are regulation, education and sustainability of value-added stakeholders. Klettner et al. (2014) empirically investigate whether the corporate governance practices and corporate structures are used by Australian companies to create, develop, and implement the corporate sustainability strategies. They indicate that big listed Australian companies tend to integrate the sustainability activities within their core business operations. They found evidence that leadership structure is designed to involve the board of directors and senior management in sustainable development strategy and motivate them through the financial rewards to monitor the implementation of sustainability strategies. Similarly, Fernandez-Feijoo et al. (2014) found that the stakeholder pressure, including client, customers, workers, and the environment is considered a determinant of the relevant level of transparency in general and specifically sustainability reporting. They also show that firm's transparency is influenced by other determinants such as ownership type, firm size, and global economic region. Ferrero et al. (2015) reveal that the diversity of the board can improve the firm's construction of vision and strategies in a way that encourage firms to apply a relevant sustainable development approach in their business activities. Figure 1 shows the integrative relationship between the quality of corporate governance and stakeholder pressure and their impact on sustainability practices in industrial companies.

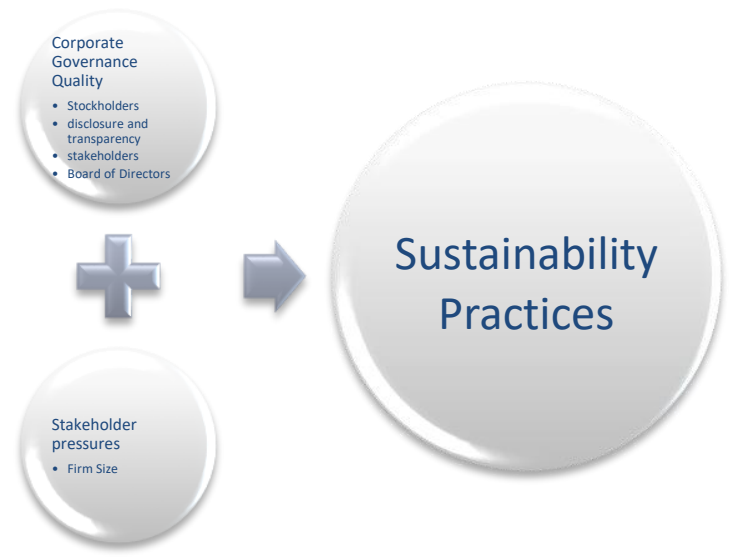

Figure 1. The relationship between quality of corporate governance and stakeholder pressure 
International Journal of Mathematical, Engineering and Management Sciences

Vol. 5, No. 6, 1077-1090, 2020

https://doi.org/10.33889/IJMEMS.2020.5.6.082

In addition, Taşkirmaz and Gamze (2017) argue that the firms tend to improve their reputation by adopting an effective corporate governance practice in alignment with the application of firm sustainability. They also suggest that there is a positive association between a firm reputation and both corporate governance and sustainability, and that there is harmony between corporate sustainability, corporate governance and a strong reputation. It can therefore be concluded that there is complementarity between the quality of corporate governance and the pressure on stakeholders to promote sustainable development of circular economy applications. Figure 1 shows the relationship between sustainability applications and the main study variables represented by the dimensions of corporate governance quality and stakeholder pressure measured by the size of the company. This study provides an opportunity for managers in industrial companies as well as investors to better understand the nature of the environment in which they work and the future directions for sustainable applications in Turkey. Moreover, the results of this study are expected to provide a guide for sustainable development policy makers in developing countries, in particular in Turkey, in drawing up sustainable development strategies in a manner that achieves the best possible results.

\subsection{Hypothesis Development}

To maximize the stakeholder's interest, the company should develop an awareness of the social and environmental consequences of the company's operations, and ensure that the company responds to the desires and opinions of those with whom it is in touch. Companies operating under a social contract may use the resources of society to produce products, but they do not have an unalienable right to use those sources. According to (Mathews, 1993), the cost-benefits rule should be taken into account when discussing the firm's right in society resources. In other words, the society will legitimate the firm only when the resources gained from resources used by the firm exceed the costs of these resources. According to Pinkse and Kolk (2010), there is an emerging overlap between corporate social responsibility and the quality of corporate governance, with firms seeking not only to increase profits but also to be ethical to operate within society. The Board of Directors, therefore, sets operational objectives and strategies within the framework of the company's social contracts, thereby ensuring the company's ability to continue and use the company's resources for production activities. Therefore, the firm with good quality corporate governance would be more environmentally responsible than other firms. Consequently, this leads to conclude that there should be a positive correlation between sustainability reporting and corporate governance quality. Based on stakeholder theory, this paper examines the following hypotheses:

\section{H1- There is a positive relationship between sustainable development and quality of corporate governance.}

A number of studies have been conducted in the last year suggesting a positive relationship between company size and social responsibility information, such as (Haniffa and Cooke, 2005; Once and Almagtome, 2014; Once and Almagtome, 2015). Such research found that larger firms are under greater pressure from the general public to provide reports of social responsibility compared to other firms, requiring these firms to respond to social, environmental and economic problems.

\section{H2- There is a positive relationship between sustainable development and firm size.}

In the same context, Tinker and Niemark (1987) indicate that community members became more aware of the adverse effects of business activities resulting from business development activities, so that legitimate constraints could force firms to react to environmental, social and economic concerns. The third hypothesis examines our main model which assumes that the sustainable development is 
International Journal of Mathematical, Engineering and Management Sciences

Vol. 5, No. 6, 1077-1090, 2020

https://doi.org/10.33889/IJMEMS.2020.5.6.082

an outcome of the interaction of different factors including, the corporate governance requirements and stakeholders' pressure together. The following multi-regression mode has been introduced to assess the mutual effect of both: the quality of corporate governance and the pressure of stakeholders on sustainable development in Turkey:

$Y=\alpha+\beta 1 x 1+\beta 2 \times 2+\varepsilon$

where:

$Y=$ dependent variable: sustainable development, it is proxied by sustainability reporting scores

(SRS).

$\alpha=$ it is a constant

$\beta 1$ to $\beta 2=$ regression coefficients of the variables $\mathrm{x} 1$ to $\mathrm{x} 2$ respectively.

$x 1$ to $x 2$ = independent variables; quality of corporate governance (CGS), and stakeholders' pressure

(measured by firm size) (FSZ) respectively.

$\varepsilon=$ error term

The following hypothesis is therefore generated for the multiple regression model:

H3- There is a positive relationship between sustainable development (SRS) and the quality of corporate governance (CGS), and Stakeholders' pressure (FSZ).

\section{Data and Method}

This paper adopts a quantitative and qualitative approach, a content analysis method, and explains sustainability reporting in a number of dimensions, including cultural, environmental and social dimensions. It also represents the consistency of corporate governance in a variety of areas, including shareholders, accountability and transparency, stakeholders and the Board of Directors. The study was conducted on the basis of an analysis of all annual reports, which are available for public consultation and cover the period from 2015 to 2017. The study examines the relationship between sustainable development (SD) as a dependent variable and both of the quality of corporate (CGQ) and firm size (as a proxy of stakeholder pressure) as an independent variable. The original sample comprises of 153 firm-year pairs of observations that cover the financial information of 48 Turkish companies indexed to BIST corporate governance by the end of 2017. Following the elimination of missing data from the sample, 125 firm-year observations were found. The analysis of the content used to evaluate the level of sustainable development reported by the sample companies utilizing a rating system relies on the global reporting initiatives. The Sustainable Development Index consists of 79 items that measure the economic, social and environmental components of sustainable development (GRI, 2006). The scoring system for every sustainability performance measure recorded by the firm is based on a score ranging from 0 to 1 . The information included in this analysis was taken from two key sources, the first being the sample companies' annual reports and the second being the corporate governance reports reported by the Turkish corporate governance organization SAHA. In order to measure the level of pressure on the stakeholder, the total assets of the company were used to be a proxy, as previous research suggests that the pressure on the stakeholder rises with the increase in firm size (Fernandez-Feijoo et al., 2014). 
International Journal of Mathematical, Engineering and Management Sciences

Vol. 5, No. 6, 1077-1090, 2020

https://doi.org/10.33889/IJMEMS.2020.5.6.082

Table 1. Descriptive statistics

\begin{tabular}{|c|c|c|c|c|c|}
\hline Variables & $\mathbf{N}$ & Minimum & Maximum & Mean & Std. Deviation \\
\hline SRS & 125 & 3.00 & 66.00 & $30 . .0160$ & 14.90615 \\
\hline $\mathrm{ECO}$ & 125 & 1.00 & 13.00 & 5.3920 & 2.40596 \\
\hline SOC & 125 & 1.00 & 25.00 & 10.7040 & 6.01346 \\
\hline ENV & 125 & 1.00 & 32.00 & 13.9200 & 7.27745 \\
\hline $\mathrm{CGV}$ & 125 & 6.91 & 9.63 & 9.1848 & .44062 \\
\hline SHAR & 125 & 4.43 & 9.76 & 9.0985 & .61460 \\
\hline DISC & 125 & 7.56 & 9.86 & 9.4218 & .41651 \\
\hline STACK & 125 & 6.42 & 9.95 & 9.4439 & .59858 \\
\hline BOARD & 125 & 5.71 & 9.65 & 8.9676 & .58315 \\
\hline FSIZ & 125 & 13.74 & 63537.00 & 8548.4063 & 12998.44352 \\
\hline Valid N (list wise) & 125 & & & & \\
\hline
\end{tabular}

The key descriptive statistics of the variables considered in the empirical model are given in Table 1. The mean of sustainable development (as the dependent variable) was 30.02, while the means of sustainable development components were 5.39, 10.70, and 13.92 respectively; economic, social, and environmental aspects. The level of corporate governance (as an independent variable) was 9.18, while the metrics for corporate governance elements were 9.10, 9.42, 9.44, and 8.97 respectively; shareholders, transparency, stakeholders, and board of directors. Finally, the mean of stakeholder pressure as an independent variable (measured by firm size) was 8,548 Million TL.

\section{Results}

The findings in Table 2 reveal the correlation coefficients between the CGV and the FSIZ as independent variables and the SRS as dependent variables. The results of the Pearson Hypothesis 1 correlation as shown in Table 2 show a strong correlation between the SRS for sustainable development and the consistency of the CGV corporate governance. This implies support for hypothesis 1 which suggests that there is a positive relationship between sustainable development and corporate governance efficiency, $\mathrm{r}(125)=.592, \mathrm{p}<.05$. The results in Table 2 also suggest a positive association (measured by total assets) between sustainable development and stakeholder pressure. This finding supports hypothesis 2 , which states that the relationship between sustainable development and firm size is positive, $\mathrm{r}(125)=.753, \mathrm{p}<.05$.

Table 2. Pearson correlation matrix

\begin{tabular}{|c|c|c|c|c|}
\hline \multicolumn{5}{|c|}{ Correlations } \\
\hline & & SRS & CGV & FSIZ \\
\hline \multirow[b]{3}{*}{ SRS } & Pearson Correlation & 1 & $.592 * *$ & $.753 * *$ \\
\hline & Sig. (2-tailed) & & .000 & .000 \\
\hline & $\mathrm{N}$ & 125 & 125 & 125 \\
\hline \multirow[b]{3}{*}{$\mathrm{CGV}$} & Pearson Correlation & $.592 * *$ & 1 & $.244 * * * 1$ \\
\hline & Sig. (2-tailed) & .000 & & .006 \\
\hline & $\mathrm{N}$ & 125 & 125 & 125 \\
\hline \multirow[b]{3}{*}{ FSIZ } & Pearson Correlation & $.753^{* * *}$ & $.244 * *$ & 1 \\
\hline & Sig. (2-tailed) & .000 & .006 & \\
\hline & $\mathrm{N}$ & 125 & 125 & 125 \\
\hline
\end{tabular}

As stated earlier, this indicates an integrated model for understanding the inclination of Turkish companies towards sustainable development activities. The suggested model integrates two main 
International Journal of Mathematical, Engineering and Management Sciences

Vol. 5, No. 6, 1077-1090, 2020

https://doi.org/10.33889/IJMEMS.2020.5.6.082

variables are the quality of corporate governance and stakeholder pressure (measured by firm size). Thus, the multiple regression model of this was designed to reflect the joint impact of the two variables. Table 3 summarizes the results of the regression model.

Table 3. Summary of regression model

\begin{tabular}{|c|c|c|c|c|}
\hline \multicolumn{5}{|c|}{ Model Summary } \\
\hline Model & R & R Square & Adjusted R Square & Std. Error of the Estimate \\
\hline 1 & $.863 \mathrm{a}$ & .745 & .741 & 7.59222 \\
\hline \multicolumn{5}{|c|}{ a. Predictors: (Constant), FSIZ, CGV } \\
\hline
\end{tabular}

The $\mathrm{R} 2$ result in table 3 is 0.74 , so the result means that the independent variables (FSIZ, CGV) will jointly explain 74 percent of the variance in the dependent variable (SRS). This indicates that the Turkish companies provide disclosure on sustainable development as a response to both of stakeholder pressure and corporate governance requirements.

Table 4. ANOVA results

\begin{tabular}{|c|l|c|c|c|c|c|}
\hline \multicolumn{7}{|c|}{ ANOVAa } \\
\hline \multirow{2}{*}{1} & Model & Sum of Squares & df & Mean Square & F & Sig. \\
\cline { 2 - 7 } & Regression & 20519.666 & 2 & 10259.833 & 177.993 & $.000 \mathrm{~b}$ \\
\cline { 2 - 7 } & Total & 7032.302 & 122 & 57.642 & & \\
\hline \multicolumn{7}{|c|}{ b. Dependent Variable: SRS } \\
\hline \multicolumn{7}{|c|}{ b. Predictors: (Constant), FSIZ, CGV } \\
\hline
\end{tabular}

Table 5. Regression coefficients of the model

\begin{tabular}{|c|c|c|c|c|c|c|}
\hline \multicolumn{7}{|c|}{ Coefficients a } \\
\hline \multirow{2}{*}{\multicolumn{2}{|c|}{ Model }} & \multicolumn{2}{|c|}{ Unstandardized Coefficients } & \multirow{3}{*}{$\begin{array}{l}\text { Standardized Coefficients } \\
\text { Beta }\end{array}$} & \multirow[t]{2}{*}{$\mathrm{t}$} & \multirow[t]{2}{*}{ Sig. } \\
\hline & & $\mathrm{B}$ & Std. Error & & & \\
\hline \multirow[t]{3}{*}{1} & (Constant) & -111.185 & 14.565 & & -7.633 & .000 \\
\hline & CGV & 14.682 & 1.596 & .434 & 9.202 & .000 \\
\hline & FSIZ & .001 & .000 & .647 & 13.727 & .000 \\
\hline \multicolumn{7}{|c|}{ a. Dependent Variable: SRS } \\
\hline
\end{tabular}

The findings in Tables 3, 4 and 5 suggest support for hypothesis 3, that indicates that there is a correlation between Sustainable Development (SRS) and Corporate Governance score (CGS) and Pressure of Stakeholders (FSZ), F $(2,122)=177,993$, p<.05, where F $(177,993)$ is higher than the crucial F $(24,06)$. Overall, statistical analysis findings suggest that the SRS for Sustainable Development is not driven by a single variable, but reflects an outcome of interaction between corporate governance criteria and stakeholder external pressures. Thus, in order to achieve the sustainable development strategy in Turkey, it is necessary to concentrate on supporting corporate governance procedures and increase the social scrutiny on the companies. 
International Journal of Mathematical, Engineering and Management Sciences

Vol. 5, No. 6, 1077-1090, 2020

https://doi.org/10.33889/IJMEMS.2020.5.6.082

\section{Discussion and Conclusions}

This paper suggests an integrated approach to examine the relationship between quality of corporate governance, stakeholder pressure and sustainable development activities. This approach incorporates the effects of two internal and external factors on the main components of sustainable development (social, environmental and economic). The internal factors are the components of the corporate governance index (stakeholder, stockholders, transparency and disclosure, and board of director), and the external factors represent stakeholder pressures. Sustainability reporting is a metric for sustainable development, while the quality of corporate governance is measured by corporate governance rating scores and stakeholder pressure is measured by total assets. The study adopts the quantitative method using the financial data extracted from the financial reports and corporate governance reports of 51 Turkish companies listed on Istanbul Stock Exchange for the period between 2015-2017. A multiple regression model has been developed to achieve the objectives of the analysis. The results show that there is a positive correlation between sustainable development and the quality of corporate governance practices, and companies with a high corporate governance record tend to disclose more economic, social and environmental information.

The results also indicate that there is a positive correlation between the sustainable development and stakeholder pressure (measured by firm size), and the big companies tend to disclose more economic, social, and environmental information. The results also show that sustainable development is influenced by internal and external factors: corporate governance procedures adopted by the companies and the pressure applied by different groups of stakeholders. Management of Stakeholder Relations received considerable attention from firms operating in efficient capital markets, particularly in those countries with environmental-oriented economies, as firms are faced with a significant change in the extent of the complexity of these relationships. Therefore, the alignment of the three pillars of sustainability, cultural, social and environmental objectives would lead to a shift in the vision of disclosure management and transparency as a whole. This could be accomplished by highlighting the connection between environmental, social and economic responsibilities which lead to the fulfillment of stakeholder expectations. This concept is mainly influenced by both sustainability and stakeholder theory. Stakeholder value development relies on the company's performance in sustainability management activities, and therefore sustainability reporting rates are used as a metric for assessing this performance. This study provides a new insight into firm-level differences in sustainability reporting practices and provides a better understanding of the relationship between sustainable development and the company's internal and external environment. The findings indirectly inspire regulators to support the company's sustainable development activities.

The main contribution of this study is to identify the determinants of sustainable development of the circular economy in Turkey by offering a scientific explanation based on two main pillars: the quality of corporate governance and the theory of stakeholders. We introduced an integrated approach to evaluating current and future developments in sustainability practices in Turkish businesses, which offers a more appropriate understanding of sustainable applications through which such applications can be improved in the future. The results show that awareness of the determinants of sustainable applications of the circular economy is essential for improving the effectiveness of sustainable development policies and thus for improving sustainable manufacturing applications in manufacturing companies in Turkey. Governments must therefore prioritize the improvement of corporate governance standards, as well as the focus on small and medium-sized enterprises to be incorporated into national sustainable development strategies. This study will also assist company managers in formulating strategies to optimize the use of available resources and to reduce waste in the context of the circular economy. 
International Journal of Mathematical, Engineering and Management Sciences

Vol. 5, No. 6, 1077-1090, 2020

https://doi.org/10.33889/IJMEMS.2020.5.6.082

\section{Conflict of Interest}

The authors confirm that there is no conflict of interest to declare for this publication.

\section{Acknowledgments}

The authors express their appreciation to the colleagues who reviewed this paper and offered useful recommendations for improving it. The authors greatly appreciate the time and useful suggestions from guest editors and reviewers.

\section{References}

Ahuja, J., Panda, T.K., Luthra, S., Kumar, A., Choudhary, S., \& Garza-Reyes, J.A. (2019). Do human critical success factors matter in adoption of sustainable manufacturing practices? An influential mapping analysis of multi-company perspective. Journal of Cleaner Production, 239, 117981.

Ali, M., Hameedi, K., \& Almagtome, A. (2019). Does sustainability reporting via accounting information system influence investment decisions in Iraq? International Journal of Innovation, Creativity and Change, 9(9), 294-312.

Almagtome, A. (2015). Effect of national cultural values on corporate environmental disclosures: a comparative study. Unpublished Doctoral Dissertation submitted to School of Social Sciences in Anadolu University.

Almagtome, A., Shaker, A., Al-Fatlawi, Q., \& Bekheet, H. (2019). The integration between financial sustainability and accountability in higher education institutions: an exploratory case study. International Journal of Innovation, Creativity and Change, 8(2), 202-221.

Almagtome, A., Almusawi, I., \& Aureaar, K. (2017). Challenges of corporate voluntary disclosure through the annual reports: evidence from Iraq. World Applied Sciences Journal, 35(10), 2093-2100.

Al-Wattar, Y.M.A., Almagtome, A.H., \& AL-Shafeay, K.M. (2019). The role of integrating hotel sustainability reporting practices into an accounting information system to enhance hotel financial performance: evidence from Iraq. African Journal of Hospitality, Tourism and Leisure, 8(5), 1-16.

Aras, G., \& Crowther, D. (2008). Governance and Sustainability: An investigation into the relationship between corporate governance and corporate sustainability. Management Decision, 46(3), 433-448.

Boeva, B., Zhivkova, S., \& Stoychev, I. (2017). Corporate governance and the sustainable development. European Journal of Economics and Business Studies, 3(1), 17-24.

Chan, M.C., Watson, J., \& Woodliff, D. (2014). Corporate governance quality and CSR disclosures. Journal of Business Ethics, 125(1), 59-73.

De Villiers, C., Naiker, V., \& Van Staden, C. (2011). The effect of board characteristics on firm environmental performance. Journal of Management, 37(6), 1636-1663.

Esen, K., Erdur, D., \& Karabiyik, L. (2015). Effects of corporate governance level on the financial performance of companies: a research on BIST corporate governance index (XKURY). Ege Akademik Bakıs Dergisi, 15(2), 265-274.

Esty, D.C., \& Winston, A.S. (2008). Green to gold: how smart companies use environmental strategy to innovate, create value, and build competitive advantage. Wiley, New York.

Fernandez-Feijoo, B., Romero, S., \& Ruiz, S. (2014). Effect of stakeholders' pressure on transparency of sustainability reports within the GRI framework. Journal of Business Ethics, 122(1), 53-63.

Ferrero-Ferrero, I., Fernández-Izquierdo, M.Á., \& Muñoz-Torres, M.J. (2015). Integrating sustainability into corporate governance: an empirical study on board diversity. Corporate Social Responsibility and Environmental Management, 22(4), 193-207. 
International Journal of Mathematical, Engineering and Management Sciences

Vol. 5, No. 6, 1077-1090, 2020

https://doi.org/10.33889/IJMEMS.2020.5.6.082

Freeman, R.E. (2010). Strategic management: a stakeholder approach. Cambridge University Press, USA.

Geissdoerfer, M., Savaget, P., Bocken, N.M., \& Hultink, E.J. (2017). The circular economy-a new sustainability paradigm? Journal of Cleaner Production, 143, 757-768.

Genovese, A., Acquaye, A.A., Figueroa, A., \& Koh, S.L. (2017). Sustainable supply chain management and the transition towards a circular economy: Evidence and some applications. Omega, 66(Part B), 344357.

GRI (2006). Sustainability Reporting Guidelines, Version 3.0. NY: Global Reporting Initiative.

Haniffa R.M., \& Cooke, T.E. (2005). The impact of culture and governance on corporate social reporting. Journal of Accounting and Public Policy, 24 (5), 391-430.

Hörisch, J., Freeman, R.E., \& Schaltegger, S. (2014). Applying stakeholder theory in sustainability management: links, similarities, dissimilarities, and a conceptual framework. Organization \& Environment, 27(4), 328-346.

James-Overheu, C., \& Cotter, J. (2009). Corporate governance, sustainability and the assessment of default risk. Asian Journal of Finance \& Accounting, 1(1), 34-53.

Kazimieras Zavadskas, E., Antucheviciene, J., \& Kar, S. (2019). Multi-objective and multi-attribute optimization for sustainable development decision aiding. Multidisciplinary Digital Publishing Institute (MDPI). ISBN 978-3-03921-142-5 (Pbk); ISBN 978-3-03921-143-2 $\quad$ (PDF) https://doi.org/10.3390/books978-3-03921-143-2.

Khaghaany, M., Kbelah, S., \& Almagtome, A. (2019). Value relevance of sustainability reporting under an accounting information system: Evidence from the tourism industry. African Journal of Hospitality, Tourism and Leisure, 8(Special Edition CUT), 1-12.

Khan, S.A.R., Zhang, Y., Kumar, A., Zavadskas, E., \& Streimikiene, D. (2020). Measuring the impact of renewable energy, public health expenditure, logistics, and environmental performance on sustainable economic growth. Sustainable Development, https://doi.org/10.1002/sd.2034.

Klettner, A., Clarke, T., \& Boersma, M. (2014). The governance of corporate sustainability: empirical insights into the development, leadership and implementation of responsible business strategy. Journal of Business Ethics, 122(1), 145-165.

Kocmanová, A., Hřebíček, J., \& Dočekalová, M. (2011). Corporate governance and sustainability. Economics and Management, 16, 543-550

Kumar, A., Choudhary, S., Garza-Reyes, J., Kumar, V., Khan, S., \& Mishra, N. (2020a). Analysis of critical success factors for implementing industry 4.0 integrated circular supply chain-Moving towards sustainable operations. Production Planning and Control.

Kumar, A., Moktadir, A., Liman, Z.R., Gunasekaran, A., Hegemann, K., \& Khan, S.A.R. (2020b). Evaluating sustainable drivers for social responsibility in the context of ready-made garments supply chain. Journal of Cleaner Production, 248, 119231.

Luthra, S., Kumar, A., Zavadskas, E.K., Mangla, S.K., \& Garza-Reyes, J.A. (2020). Industry 4.0 as an enabler of sustainability diffusion in supply chain: an analysis of influential strength of drivers in an emerging economy. International Journal of Production Research, 58(5), 1505-1521.

Mangla, S. K., Luthra, S., Jakhar, S., Gandhi, S., Muduli, K., \& Kumar, A. (2020). A step to clean energySustainability in energy system management in an emerging economy context. Journal of Cleaner Production, 242, 118462.

Mangla, S.K., Sharma, Y.K., Patil, P.P., Yadav, G., \& Xu, J. (2019). Logistics and distribution challenges to managing operations for corporate sustainability: Study on leading Indian diary organizations. Journal of Cleaner Production, 238, 117620. 
International Journal of Mathematical, Engineering and Management Sciences

Vol. 5, No. 6, 1077-1090, 2020

https://doi.org/10.33889/IJMEMS.2020.5.6.082

Mathews, M.R. (1993). Socially responsible accounting. London: Chapman and Hall.

Michelon, G., \& Parbonetti, A. (2012). The effects of corporate governance on sustainability disclosure. Journal of Management and Governance, 16 (3), 477-509

Moktadir, M.A., Rahman, T., Rahman, M.H., Ali, S.M., \& Paul, S.K. (2018). Drivers to sustainable manufacturing practices and circular economy: A perspective of leather industries in Bangladesh. Journal of Cleaner Production, 174, 1366-1380.

Once, S., \& Almagtome, A. (2014). The relationship between Hofstede's national culture values and corporate environmental disclosure: An international perspective. Research Journal of Business and Management, 1(3), 279-304.

Once, S., \& Almagtome, A. (2015). The impact of national cultural values on environmental reporting: a comparative study. Economic and Social Development (Book of Proceedings), 5th Eastern European Economic and Social Development, pp. 251-260, 21-22 May, 2015, Belgrade, Serbia.

Panda, T.K., Kumar, A., Jakhar, S., Luthra, S., Garza-Reyes, J.A., Kazancoglu, I., \& Nayak, S.S. (2020). Social and environmental sustainability model on consumers' altruism, green purchase intention, green brand loyalty and evangelism. Journal of Cleaner Production, 243, 118575.

Pinkse, J., \& Kolk, A. (2010). Challenges and trade-offs in corporate innovation for climate change. Business Strategy and the Environment, 19(4), 261-272.

Salvioni, D.M., \& Astori R. (2013). Sustainable development and global responsibility in corporate governance. Symphonya Emerging Issues in Management, 1, 28-52.

Schaltegger, S., Lüdeke-Freund, F., \& Hansen, E.G. (2012). Business cases for sustainability: the role of business model innovation for corporate sustainability. International Journal of Innovation and Sustainable Development, 6(2), 95-119.

Schroeder, P., Anggraeni, K., \& Weber, U. (2019). The relevance of circular economy practices to the sustainable development goals. Journal of Industrial Ecology, 23(1), 77-95.

Sehnem, S., Pandolfi, A., \& Gomes, C. (2019). Is sustainability a driver of the circular economy? Social Responsibility Journal, 16(3), 329-347.

Siva, V., Gremyr, I., Bergquist, B., Garvare, R., Zobel, T., \& Isaksson, R. (2016). The support of Quality Management to sustainable development: a literature review. Journal of cleaner production, 138(part 2), $148-157$.

Snider, J., Hill, R.P., \& Martin, D. (2003). Corporate social responsibility in the 21st century: A view from the world's most successful firms. Journal of Business Ethics, 48(2), 175-187.

Taşkirmaz, M. \& Gamze, C. (2017). Relationship between corporate governance, corporate sustainability and corporate reputation: a sample of borsa Istanbul. Yönetim \& Ekonomi, 24(2), 469-483.

Tinker, T., \& Neimark, M. (1987). The role of annual reports in gender and class contradictions at General Motors 1917-1976. Accounting, Organizations and Society, 12(1), 71-88.

Witjes, S., \& Lozano, R. (2016). Towards a more circular economy: proposing a framework linking sustainable public procurement and sustainable business models. Resources, Conservation and Recycling, 112, 37-44. 